\title{
The lack of topographic mapping and the historical problem of land demarcation in Brazil
}

\author{
Claudia Robbi Sluter ${ }^{\mathrm{a},}$ *, Andrea Lopes Iescheck ${ }^{\mathrm{a}}$, Andrea Flávia Tenório Carneiro ${ }^{\mathrm{b}}$, Daniela \\ Regina Pontes ${ }^{\text {c }}$, José Antônio Peres Gediel ${ }^{\mathrm{d}}$ \\ ${ }^{a}$ Federal University of Rio Grande do Sul, Department of Geodesy, robbi.sluter@ufrgs.br, andrea.iescheck@ufrgs.br \\ ${ }^{b}$ Federal University of Pernambuco, Department of Cartographic Engineering, andreaftenorio@gmail.com \\ ${ }^{c}$ Federal University of Parana, Department of Geomatics, danielepontes.ufpr@gmail.com \\ ${ }^{d}$ Federal University of Parana, Department of Private and Procedural Law, jagediel@ gmail.com \\ * Corresponding author
}

Keywords: Topographic mapping, Land demarcation, National mapping

\begin{abstract}
:
This paper presents the arguments to propose a research project whose primary goal is to identify topographic mapping deficiencies in its relationship with the current regulatory framework in the Brazilian legal system. The motivation for proposing this research study is a problematic chronological discrepancy between the territory occupation, legislation, and mapping. We assume this as a problematic discrepancy because some fundamental human rights are impossible to achieve if there are no updated topographic maps at suitable scales. We also assume that there is a historical problem due to political motivation since the Portuguese crown colonization.
\end{abstract}

The Brazilian colonial state policy that held the entire territory's domain defined the first phase of the Brazilian territorial occupation and land legislation evolution. Its purpose was to assign private property to the groups that supported the monarchical government. The history of mapping the Brazilian territory started at the end of this period, with the first astronomical observations in Rio de Janeiro and São Paulo from 1781 to 1795. Therefore, the Brazilian territory occupation occurred without being correctly mapped and, thus, be unknown in around 300 years. Consequently, there was a gap in land registration in allocating public lands to private individuals in the Brazilian Empire's territory domain. This fact led the Brazilian agrarian economy to seek an expansion of land properties through the legal status of possession.

The next moment coincides with the first attempt of modernization (understanding legal modernity based on individual private property) by establishing public lands to transfer them just to those who had access to the state apparatus (Land Law of 1850). This Law was regulated by decree 1318 of 1854, which determined the land measurement and created the Commissioner Judge of Measurements. However, these processes occurred without having a particular concern with the cartographic aspects related to the precise demarcation of land boundaries, i.e., the concern was only with the boundaries of the Colony and Empire, but not with the boundaries of the domains and possessions of subjects.

In 1864, almost 100 years after the first astronomical observations, there was an attempt to map Brazil based on technical and scientific criteria, creating the Commission of the General Map of the Empire. The commission's mission was to establish a geodetic referential using triangulation and produce topographic maps at 1:1.000.000 for the entire Brazilian territory. Unfortunately, because of the accuracy and precision problems of the results of this mapping mission, the only result was a map published at the 1: 3,710,220 scale, called the Map of the Empire of Brazil. The Map of the Empire was presented at the Vienna National Exhibition in 1875 and the 1876 Philadelphia Universal Exhibition. It is more an illustration than the results of a topographic mapping as demanded by the emperor in 1864 .

The first step towards considering the precise demarcation of properties took place in the republican period. In 1901, the Ministry of Military Defense proposed a project called "General Map of Brazil" in order to produce a topographic map using geodetic, astronomical, topographic, and cartographic operations. This project established survey procedures, map projections, scales, and map formats for the General Map of Brazil. This project's execution began in 1903, with the General Map Commission's settlement in Porto Alegre - Rio Grande do Sul State. The results, however, were far below planned. It was supposed to make 3,000 sheets at the 1:100,000 scale, but the commission could finish just 53. Several problems that occurred since 1922 prevented the last years of activity of the General Map Commission from getting along, and, in 1930, practically all the works were ceased.

Although the lack of topographic mapping at large scales, with the Civil Code of 1916, it was possible to acquire a property by transcribing titles in the Land Registration Office. In 1922, the Brazilian territory was completed mapped at a 1:1,000,000 scale. The 1939 Code of Civil Procedure introduced the Torrens land title registration system and enabled the acquisition and loss of land. 
Despite having the whole Brazilian territory mapped at 1:1.000.000 only, the Federal Constitution of 1946 defined the basis for the new agrarian legislation, establishing the use of the property for social welfare. Years later, the Land Statute (Law 4504/1964) created the Brazilian Institute of Agrarian Reform and the National Institute for Agrarian Development and, in 1966, the National Agrarian Reform Program. In 1967, the decree-law n ${ }^{\circ} 243$ set the guidelines and bases for Brazilian reference cartography. In 1972, decree $n^{\circ} 5868$ determined the creation of the National System of Rural Cadastre (SNCR), whose main goal was to promote integration and systematization of the collection, search, and processing of data and information about land use and possession. Decree 72106 regulated the SNCR in 1973, and, in the same year, the Law of Public Records (Law 6015) was approved.

However, during these decades, there have been a few topographic mapping works. For example, in 1946, the beginning of the São Francisco Valley and the State of Bahia mapping at 1:250,000 scale. In 1978, the Brazilian government approved the National Mapping Program to perform the systematic mapping at 1:100,000 and 1: 250,000 scales, which should be completed by 1985. Today, the completed coverage of topographic mapping of Brazilian territory is at 1:250.000 and 1:1.000.000 scales only. The 1:50.000 topographic maps only .cover $24 \%$ of the territory. Nevertheless, $58 \%$ of those maps were published before 1998, most in the 1960s and 1970s.

According to the 1988 Federal Constitution, the federal government is responsible for organizing and maintaining the national cartographic system. Despite the constitutional obligation, the Cartography Commission (COCAR) was deactivated in 1990 and reactivated in 1994 as National Cartography Commission (CONCAR), with the duties of advising the Minister of State in the National Cartographic System (SCN) and coordinating the execution of the National Cartographic Policy. Today, the website of CONCAR < https://www.concar.gov.br/> is inoperative, and the last official meeting, published on the Ministry of Planning website, occurred on November, 23rd 2018.

From the Colony to the Republic, we note the chronological mismatch between the legislation (the occupation of the territory) and mapping (the territory knowledge). It follows that Cartography and Law, as they stand, are products of the same historical time and serve the purposes of colonial conquest and national states. The beginning of the 19th century, given the States' configuration and the concern with territorial control and planning, changed the notion of mapping and territorial rights. With the Napoleonic Cadastre, France changed the size, scale, and map contents simultaneously that the Napoleonic Civil Code established the new property figures of the land, with the emergence of the public-private division and the regime of properties and possessions. Influenced by European models, though in a diverse context and conditions, attempts were made to establish state policies in Brazil, especially in the post-independence period. These policies provided the implementation of cartographic bases and the inauguration of regulations on the disposition of public lands to create private properties, which can be observed initially in the advent of the Land Law in 1850. Given the precarious conditions and the utterly hostile environment to such novelties, we lack concurrence between discourse, practice, and reality. From the Cartography standpoint, illustrative nature's distortions in the "Map of the Empire of Brazil" are in conjunction with the new provision for private property defined in Brazil's first Constitution (1824). This property regime provided the exact definition of territorial units, which constitutes an "institutional untruth."

Cartography and Law can identify contradictions and gaps that have increased inequality and territorial injustice by critically reviewing such a process. We understand that knowledge about the territory means power over the definition of the population's life and space structuring. Moreover, advancing the reading of territorial issues also allows contemporary instruments, such as territorial cadastres, to consign the diversity of themes that generate the representation, the analytical understanding of the land, and the plurality of public policies that impact new territorial realities.

The full paper has been published in the Brasilian Journal of Cartography (Revista Brasileira de Cartografia, v. 72, p. 916-939, 2020) at: https://doi.org/10.14393/rbcv72nespecial50anos-56599 